\title{
Effective Communication in Politics. Barack Obama's Inspirational Speeches
}

\author{
Lect. Laura IRIMIEȘ, PhD \\ Department of Journalism \\ Faculty of Political, Administrative and Communication Sciences \\ Babes-Bolyai University, Cluj-Napoca, Romania \\ E-mail: laura.irimies@fspac.ro
}

\section{Prof. Cosmin IRIMIEȘ, PhD}

Department of Communication, Public Relations and Advertising Faculty of Political, Administrative and Communication Sciences Babes-Bolyai University, Cluj-Napoca, Romania

E-mail: cosmin.irimies@fspac.ro

\begin{abstract}
Mastering effective communication skills has become, over the last decades, one of the most important features of the contemporary social animal that is the human being. Not accidentally have we chosen this particular definition of human being, but with the clear intention of underlining and emphasizing the importance communication has in the modern social construction. As a social animal, the human being is subject to power relations that either raise or destroy him. And the place each human claims within the social hierarchy directly depends on the particular level of mastering effective communication. Effective communication is more important, even vital in politics, where everything is directly depending on message, meanings and ways of expressing and exposing them. We chose to focus on political and electoral communication, narrowing the study cases to one of the outstanding speeches of the American President Barack Obama's, as it reflects not only all theories on effectiveness in communication, but proved to be of major impact on the American society, leading to the repeated election of the first African
\end{abstract}


American president of the United States of America. The study case primarily approaches the meanings that gave relevance to Barack Obama's speech at the 2004 Democratic National Convention in Boston, a speech that is considered decisive for his presidential career.

Keywords: Communication; Public speaking; Speech; Effectiveness; Message; Meaning; Impact.

\section{Introduction}

Any attempt to determine the importance of non-verbal communication within the process of effective communication must start with defining a set of essential concepts to operate with. First of all we must accede to a clear, comprehensive and relevant definition of communication, as scholars offered an extremely wide variety of interpretations and a multitude of different perspectives on this subject. While early researchers see communication as the simple process of transferring / sending and receiving / information through a previously defined channel, from one place or person to another, the studies later refined the definition by introducing new elements to the first major, but rather simple communication model introduced in 1949 by Claude Shannon and Warren Weaver. Their initial model consisted of three primary parts: sender, channel, and receiver, the first being the one who initiated the informational transfer and established which specific channel to be used, while the latter had the only mission of receiving and absorbing information.

Basically seen as the process of sending and receiving information, communication is now defined by Manuel Castells (2009) as sharing of meaning through the exchange of information between different actors in specific contexts. We can see thus a subtle transition from the sending-receiving information to actively sharing and exchanging meanings or meaningful information, important both for the sender and the receiver that can at any moment change places.

Communication gets to the point where it is no more a simple process, but a situational and behavioral context, where people with certain common interests and constraints constantly and actively exchange important and meaningful information trying to guide others positions and using a wide range of communication tools to support their endeavor (Castells 2009).

One of the most important features of an effective communication process is that it doesn't simply imply manipulating words with the purpose of transmitting information or even reproducing already existing meanings just to pass them over to new actors, but its essence is to create genuine and significant meanings and therefore to enrich the existing reality and help a new one emerge. 
As scholars used to say, communication "does not find a world already built that it would settle to utter. It produces this world by commanding it to show itself. Object after object it places the world in relation with the discourse" (Laurent 1999), being seen thus as an event in itself, placed in a social and cultural context that influence it (Benveniste 2000).

The French philosopher Paul Ricoeur (1999) at his turn depicts two major dimensions of the discourse and consequently of communication: event and meaning. According to his research, to assess only the event dimension would imply that all communication is temporary and the meaning is an irrelevant component as compared to all other features.

Communication stands thus at the intersection of individual behavior and social framework, its success of failure being directly determined by a whole set of interactive factors and circumstances, such as: the message, the meaning, the moment, the space, the context of the communication process, the speaker's force, position and skills, the receiver's abilities to decode and interpret, his/her willingness to accept, process, develop, alter or reject the meaning. In other terms, any communication act implies:

-Social actors with determined backgrounds;

-Chosen roles and relationships established due to these roles;

- A well determined physical context;

- An assumed and interiorized socio-cultural context (Radu 2013).

According to Albert Mehrabian (1971) stated, the most important elements that can determine the success or failure of the exchange of meanings are the body language, the paralanguage and only then the words we use to communicate. Thus, in a communication sequence one understands the message $7 \%$ from verbal content, 38\% from vocal information and 55\% from the speaker's body language (Mehrabian 1971), a theory Merhabian reiterated in 1981 and later.

Although the balance is not relevant for all communication situations, it can be generally accepted as model for direct communication, public speaking or persuasion acts where effectiveness is given by the way the audience receives, interprets and takes over the meanings shared by the speaker.

As a most common perception, there are four levels of communication, presented by Arthur Berger (1995). The intra-personal communication is the most profound level of communication that precedes and constitutes basis for all other levels and forms of communication. The second level is that of inter-personal communication represents an interaction between two persons with common interests and backgrounds that share and exchange information. The group communication occurs when three or more persons perceive themselves as belonging to, or being identified with a group, sharing meanings, concepts and situations. The most complex form of direct communication is the public communication that occurs in 
a more formal and structured setting with one or more speakers and a variety of listeners or a wide and sometimes heterogeneous audience that has to be attracted and even persuaded.

We would add here mass communication also, a process through which a person, certain group of people or an organization makes use of a channel of communication in order to deliver a predefined message to a large group of anonymous and heterogeneous people and organizations, known as the general public. Seen from the perspectives presented above, effective communication is strongly and directly related to and influenced by the effect it has on the audience no matter how large it is. Public communication has become completely tied to effective communication skills and abilities, especially political figures turning it into science conducted by very clear and specific rules.

Mastering public speaking techniques, argumentative speech strategies and academic public debate has become vital over the last decades under the circumstances of fierce competition among political, social and economic actors. And where else to undertake a more relevant analysis on effective communication and public speeches than in electoral campaigns originally and constantly designed to achieve major influence and persuasive effects on extremely large masses of people?

The American political and electoral public speeches date back in the 1960's, when the first broadcasted presidential debate is conducted having as leading actors the two candidates running for President: John F. Kennedy and Richard Nixon. They opened the way to politic debates, public speaking shows and led to public speaking becoming compulsory discipline of study for secondary and high school students.

Public communication developed a clear set of guiding principles and rules that are still valid, bud undertake continuous improvement as public actors become more and more aware of the importance of every detail that can make a difference. Public speaking become more and more focused on comprehensive approach, thorough research of the audience, precision of details, clarity, but also politeness and most important, empathy. Empathy led to motivational and inspirational speeches that made ordinary people leaders and even presidents.

\section{Barack Obama - speeches that can win elections}

One of the most relevant cases supporting the statements above is that of Barack Obama, the $44^{\text {th }}$ president of the United States of America and the first African American that became president of the USA. Most of his success in acceding to the White House Office is due to the force of his speech.

Extremely illustrative for this is the speech that is considered to have made Barack Obama president of the United States of America, by bringing him to light as an exceptional and consistent public speaker. This is the main reason we have 
approached the particular speech that Barack Obama held at the 2004 Democratic National Convention in Boston, when his only advantage was that of being seen as a young hope rising in the party. Right from the beginning, the young man, a oneterm senator from Illinois chosen to deliver the keynote speech at the Democratic National Convention in Boston was folding his story into the story of the American people, making his dramatic entrance into the national conscience: "Let's face it. My presence on this stage is pretty unlikely. My father was a foreign student born and raised in a small village in Kenya (...). My parents shared not only an improbable love. They shared an abiding faith into the possibilities of this nation. I stand here knowing that my story is a part of the larger American story, that I owe a debt to all of those who came before me, and that in no other country on Earth is my story even possible" (Barack Obama's speech from 2004).

Finding common ground and integrating with the audience go over the years as one of the most important and successful ways Barack Obama the speaker gets full attention and empathy. Moreover, he personalized every feature of his 2004 audience, by referring to each important social category, from women to jobless people, from unschooled children to ill and poor elder people, reassuring the audience that each of their problems was his personal issue as it was the nation's: "It is the fundamental belief 'I am my brother's keeper', 'I am my sister's keeper' that makes this country work" (Barack Obama's speech from 2004).

The speech in Boston 2004 gives a preview of the future candidate's entire political message in 2008 running for the White House, so as for the people to become aware of the real issues he would approach.

Even from the announcement of the major issues, Barack Obama refers to the counter-strikers, presenting them as "the ones preparing to device, the spin masters (...) who embrace the politics of anything goes". The light under which his opponents are presented is a subtle but really negative one for an audience dedicated to action, to anything but the politics of indifference he recalls, so as for him to take a real advantage he could eventually build on.

He makes use of the essential values of the American nation, appearing to cross over political differences.

According to analysts, there are at least three things that made the Obama 2004 speech really effective: use of concrete details, liking the story and use of antithesis designed to oppose the United States of America to any disruptive concept. "There is not a liberal America of a conservative America, there is the United States of America. There is not a black America, a white America, a Latino America, an Asian America, there are the United States of America" Barack Obama's speech from 2004).

He spoke about hope, about audacity, equity, discrimination and even God. And he once more subtly connected to his predecessors and the American dream: 
"I believe that this country will reclaim its promise and out of this long political darkness a brighter day will come" (Barack Obama's speech from 2004).

In asserting all his powerful ideas and concepts, Barack Obama saves no energy. He fully uses non-verbal and body language to support each and every word. Nonverbal communication holds a great importance in communication and it describes the process of conveying meaning in the form of non-word messages. Research shows that the most part of our communication process is non-verbal (body language) (Pease \& Pease 2004).

The nonverbal communication is formed by gestures and touch, body language or posture, physical distance, facial expression and eye contact. Also, the voice holds a really big importance in non-verbal communication. It is not all about what you say, but about how you say it. Likewise, written texts have nonverbal elements such as handwriting style, spatial arrangement of words, or the physical layout of a page (Fast 1970).

The 2004 Barack Obama uses hands, uses mimics, frowns, smiles, overall kinesics, all in order to give the clear and strong message of change through young, strong, dynamic people. And all above mentioned are fully adapted to the message.

He succeeded in verbally and non-verbally delivering an electrifying speech on hope for each and every American citizen, determining analysts to consider the speech held at the 2004 Democratic National Convention in Boston as the moment that really made Barack Obama President.

Leaping to the nowadays President Barack Obama, we can see a major change of attitude in delivering speeches, as he is a little more reserved, solemn, much more official and immobile, and perhaps more effective for his Office and Presidential engagements. Out of this solemnity and reserve, the last speeches held on various occasions as good-bye speeches on his last days at the White House reveal that the extremely dynamic strong public speaker has undertaken a necessary refinement due to the official position, but the very appealing and direct speaking style is a natural one.

"As a package of talents, he (Barack Obama) is close to be, probably the greatest president ever if you measured it simply by his ability to speak, his ability to move people with his rhetoric, his mind" (Mario Cuomo, former Governor of New York, in Ron Reagan Show - Air America, August 11 ${ }^{\text {th }}, 2009$ ).

As we can see, the effectiveness of communication and public speaking in politics can be decisive for a career or even for a nation's course, as it may lead to electing representatives and presidents, imposing of political and economic measures.

The set of rules which guide effective communication is though not a static one, as it refines and enlarge according to various situations and to the audience's expectations, features, background and context. 
The field of effective communication must be subjected to continuous approach as its dynamics requires permanent monitoring and evaluation, but the basic principles can be found in each of the major political speeches and mastering them and the effective communication techniques can be decisive.

\section{Final remarks}

Public speech has an extremely important historical background that goes back to Ancient Greek who's well known and influential orators like Plato or Aristotle have set basis to what would develop in later regulations of public communication.

Much later (Irimieș 2013), philosophers have described critical argument as a very important feature of the development of human thinking. Public debates for social participation, parliamentary or electoral debates, also scientific or economic debates appear every time citizens do not agree over a certain subject and decide to expound their points of view using arguments.

The more advanced educational systems have raised the importance of improving communication skills to research and study level and so public speaking became part of the educational curriculum. England has set the tone in 1815 through the constituency of Cambridge Union Society that invited important political figures of Great Britain to debate against the university's students, their example being followed in 1823 by Oxford, after which it became a general practice in every British university (Irimieș 2013).

According to the same author, she second largest wave of this kind was noticed after the $2^{\text {nd }}$ World War in the United States of America. On a background of unparalleled economic growth and rise of living standards, public debates have become more and more popular, generating, in the 1960's, the first televised Presidential debates between Richard Nixon and John Kennedy.

While in their early ages presidential debates used to end an electoral campaign and just confirm or strengthen the candidates' position in electoral polls, they slowly got to have a much bigger importance during different stages of political competitions and became natural features of every modern electoral campaign. The last decades' electoral experience shows that Western countries, with a strong and consolidated tradition in public debates have been, electoral debates performed either on TV or in front of large masses of voters got to be thoroughly prepared as they are most of the times decisive for the final election's result.

Even more, a strong well sustained, charismatic and memorable speech may be exactly the kind of element that can turn a common politician into a future candidate to Presidency. This kind of practice is more and more used in Western European consolidated democracies, where public appearances of political representatives can give early hints on who the next candidates would be or on their evolution during electoral campaigns. 
Unfortunately, Eastern Europe countries still lack this practice and use public debates as final round in the electoral fight, most of the times during the very last days of campaign when the majority of voters had already chosen. Inspirational speeches and Western practices, especially the American ones definitely are a model to be seriously considered by Eastern political actors and also by researchers as they can be real trendsetters for future political course in this part of Europe.

\section{References}

1. Benveniste, E. (2000). Probleme de lingvistică generală. Bucharest: Ed. Universitas.

2. Berger, A. (1995). Essentials of Mass Communication Theory. California: Sage Publications.

3. Castells, M. (2009). Communication Power. Oxford University Press.

4. Dillard, J.P., Pfau, M. (2002). The Persuasion Handbook: Developments in Theory and Practice, $2^{\text {nd }}$ Edition. California: Sage Publications.

5. Fast, J. (1970). Body Language - The Essential Secrets of Non-verbal Communication. New York, NY: MJF Book.

6. Hargie, O. (2004). The Handbook of Communication Skills, $2^{\text {nd }}$ Edition. Routledge.

7. Hollihan, T.A., Baaske, K.T. (2005). Arguments and Arguing, The Products and Process of Human Decision Making, Second Edition 2005. Long Grove, IL: Waveland Press.

8. Irimieș, C. (2013). Effective communication - an essential step towards public success, Journal of Media Research, 1(15) / 2013: 37-42.

9. Jenny, L. (2009). La Parole singulière. Bellin-Paris.

10. Mehrabian, A. (1971). Silent Messages. Belmont, CA: Wadsworth Publishing Company.

11. Pease B., Pease A. (2004). The Definitive Book of Body Language. New York, NY: Bantam Books.

12. Radu, C. (2013). The discourse - Major meanings of a complex notion, Revista Transilvană de Ştiinţe ale Comunicării.

13. Ricoeur, P. (1999). Eseuri de hermeneutică. De la text la acţiune. Cluj-Napoca: Ed. Echinox.

14. Stanton, N. (2009). Mastering Communication. Palgrave Macmillan. 